\title{
Morpho-Agronomic Characterization and Evaluation of In-Country Sweet Potato Accessions in Southeastern Nigeria
}

\author{
I. I. M. Nwankwo ${ }^{1}$, E. E. Bassey ${ }^{2}$, S. O. Afuape ${ }^{1}$, J. Njoku ${ }^{1}$, D. S. Korieocha ${ }^{1}$, G. Nwaigwe ${ }^{1} \&$ T. N. C. Echendu \\ ${ }^{1}$ National Root Crops Research Institute, Umudike, Nigeria \\ ${ }^{2}$ Department of Crop Science, Faculty of Agriculture, University of Uyo, Nigeria \\ Correspondence: E. E. Bassey, Department of Crop Science, Faculty of Agriculture, University of Uyo, Nigeria. \\ E-mail: emmanuelbas_129@yahoo.com
}

Received: June 29, 2012 Accepted: July 23, 2012 Online Published: October 17, 2012

doi:10.5539/jas.v4n11p281

URL: http://dx.doi.org/10.5539/jas.v4n11p281

\begin{abstract}
The experiment was conducted in 2010 and 2011 to evaluate and characterize fifteen in-country sweet potato accessions for root characteristics and root yield, plant habits, ground cover, severity of root damage by Cylas puncticollis and Meloidogyne incognita and identify duplications. Significant differences $(\mathrm{P}<0.05)$ were observed for number of roots per plot, salable roots per plot, unsalable roots per plot and root yield. The highest number of roots per plot, salable roots and root tuber yield were given by $E_{10}$, followed by $B_{21}$ while the lowest came from $\mathrm{E}_{17}$. The result indicated $\mathrm{B}_{26}$ as highly susceptible to C. puncticollis, $\mathrm{E}_{3}, \mathrm{E}_{11}, \mathrm{E}_{6}, \mathrm{E}_{27}$ and TIS 87/0087 were resistant, while $\mathrm{B}_{6}, \mathrm{E}_{5}, \mathrm{~B}_{2}, \mathrm{E}_{17}, \mathrm{~B}_{21}, \mathrm{E}_{14}, \mathrm{E}_{7}, \mathrm{~B}_{23}$ and $\mathrm{E}_{10}$ were highly resistant to the pest. Seven accessions $\left(E_{5}, B_{6}, B_{2}, E_{14}, E_{7}, B_{23}\right.$ and $\left.E_{10}\right)$ were highly resistant, five accessions $\left(E_{3}, B_{26}, E_{11}, E_{2}\right.$ and TIS 87/0087) showed moderate resistance while $\mathrm{B}_{2}, \mathrm{E}_{6}$ and $\mathrm{E}_{17}$ were highly susceptible to root knot disease. Ground cover of less than $50 \%$ was identified with $\mathrm{B}_{21}$ (erect type), the semi-erect types $\left(\mathrm{E}_{5}, \mathrm{E}_{6}\right.$, and $\left.\mathrm{B}_{23}\right)$ had ground cover of 50-75\%, while the spreading types $\left(\mathrm{B}_{6}, \mathrm{~B}_{2}, \mathrm{E}_{11}, \mathrm{E}_{17}, \mathrm{E}_{14}\right.$ and $\left.\mathrm{E}_{7}\right)$ had $76-90 \%$ ground cover. The extremely spreading types $\left(E_{3}, B_{26}\right.$ and $\left.E_{27}\right)$ had more than $90 \%$ ground cover. Six accessions $\left(E_{5}, E_{3}, E_{6}, E_{14}, B_{23}\right.$ and $\left.E_{10}\right)$ had white skin, seven $\left(\mathrm{B}_{6}, \mathrm{~B}_{26}, \mathrm{~B}_{2}, \mathrm{E}_{27}, \mathrm{E}_{17}, \mathrm{E}_{7}\right.$ and TIS 87/0087) were pale pink while two $\left(\mathrm{E}_{11}\right.$ and $\left.\mathrm{B}_{12}\right)$ were pink. The root flesh of one accession $\left(\mathrm{B}_{6}\right)$ was white, three yellow, while the remaining eleven accessions were creamy, and $\mathrm{E}_{27}$ and TIS 87/0087 were duplicates.
\end{abstract}

Keywords: characterization, evaluation, sweet potato accessions, root characteristics, Cylas puncticollis, Meloidogyne incognita

\section{Introduction}

Sweet potato (Ipomoea batatas (L) Lam) is an important food crop in the tropical and sub-tropical countries and belongs to the family convolvulaceae (Gill, 1988). It is cultivated in more than 100 countries (Woolfe, 1992). The area under sweet potato cultivation in Nigeria is estimated at about 200,000-300,000 hectares annually (Enwezor et al., 1989). Nigeria is the third largest producer in the world with China leading, followed by Uganda (FAO, 2004). Sweet potato ranks seventh among the world food crops, third in value of production and fifth in caloric contribution to human diet (Bouwkamp, 1985).

Small holder farmers have developed more interest for sweet potato production in Nigeria. This is so because sweet potato has a short gestation period of about four months and tolerates wide ecology. Once fully established, it suppresses weeds and reduces the overhead cost of production compared to cassava and yam (Chukwu, 2001; Antiaobong \& Bassey, 2008). It has high photosynthetic efficiency (Kapinga et al., 1997), and high yield per unit area and also serves as a bridge between periods of food shortages (Bouwkamp, 1985). The non-edible parts (vines) are used for planting material and so do not compete for human food, in addition to the fact that they are easy to transport to the field (Antiaobong \& Bassey, 2008).

Sweet potato blends with rice, cowpea and plantain in Nigerian diets. It is also becoming popular as a substitute to yam and garri (Chukwu, 2001). It can be reconstituted into fofoo or blended with other carbohydrate flour sources, such as wheat (Triticum aestivum) and cassava (Manihot esculenta) for baking bread, biscuits and other confectioneries (Woolfe, 1992). The leaves are rich in protein and the orange flesh varieties contain high 
$\beta$-carotene and are very important in combating vitamin A deficiency especially in children (Korieocha et al., 2009).

Several constraints limit sweet potato production world wide, notably low yield and losses due to insect pests especially the sweet potato weevils (Cylas spp.) and diseases (Chaltant et al., 1996). Others include, use of unimproved varieties and insufficient planting materials at the beginning of the cropping season (Njoku et al., 2009). Tewe et al. (2001) reported yield losses of up to $80 \%$ attributed to Cylas puncticollis, while Onwueme, (1978) reported $75 \%$ crop loss due to the insect pest alone. Yields are still low in farmers' fields ( $8 \mathrm{t} / \mathrm{ha})$ (Njoku et al., 2009). Decrease in quality salable roots has also been attributed to root tuber cracks caused by root knot nematodes (Meloidogyne spp). Due to the outcry for reduction and/or banning of the use of chemical insecticides, there is the need to develop resistant clones. Resistant and high yielding sweet potato clones have been developed at the National Root Crops Research Institute (NRCRI), Umudike and International Institute of Tropical Agriculture (IITA), Ibadan, both in Nigeria and distributed to farmers for multi-location trials in Nigeria (Kumar \& Peter, 2000).

The aim of this study was to characterize and evaluate 15 in-country sweet potato accessions for root characteristics and yield, skin and flesh colours, plant habits and ground cover, resistances to Cylas puncticollis and root knot disease and eliminate duplications.

\section{Materials and Methods}

The experiment was conducted in 2010 and 2011 farming seasons at the Experimental Farm of the National Root Crops Research Institute, Umudike, Nigeria (Longitude $07^{\circ} 34^{\prime} \mathrm{E}$ and Latitude $05^{\circ} 29^{\prime} \mathrm{N}$ and located at an altitude of $122 \mathrm{~m}$ above sea level). The purpose of the study was to evaluate and characterize fifteen in-country sweet potato accessions for yield, based on salable and unsalable root tubers, tuber characteristics (skin colour, root flesh colour), and determine severity of damage by Cylas puncticollis and root knot nematode and determine plant habits and duplication among the accessions. The sweet potato accessions were obtained from Ebonyi State and Benue States both in Nigeria. Nine accessions were obtained from Ebonyi State, namely $E_{3}, E_{5}, E_{6}, E_{11}, E_{17}$, $E_{21}, E_{7}, E_{14}$ and $E_{10}$, while five accessions were obtained from Benue State, namely $B_{6}, B_{26}, B_{2}, B_{21}$ and $B_{23}$ and TIS 87/0087 used as a check was obtained from the International Institute of Tropical Agriculture (IITA), Ibadan, Nigeria. The soil of the experimental site is classified as sandy loam ultisol. Rainfall is bimodal with an annual average of $2076.8 \mathrm{~mm}$ and the area falls within the tropical rainforest zone of Nigeria (Njoku et al., 2009). The land, previously cultivated with yam and left fallow for two years was disc ploughed, harrowed and ridged $1 \mathrm{~m}$ apart for the experiment.

The experiment occupied a land area of $15 \mathrm{~m} \times 9 \mathrm{~m}$ and was laid out in a randomized complete block design with three replications. Vine cuttings of $30 \mathrm{~cm}$ with seven nodes were obtained from healthy stem portions and sown $30 \mathrm{~cm}$ along the crest of the ridges with about three nodes buried in the soil. Each plot contained 30 plants, giving 1440 plants in the entire experimental farm. Each plot received a "blanket" application of NPK 15:15:15 fertilizer at $400 \mathrm{~kg} / \mathrm{ha}$ after hoe weeding 4 weeks after planting (WAP). Selective removal of Panicum maximum by hand pulling was done at $8 \mathrm{WAP}$.

Records were taken at 16 WAP (Ezulike et al., 2001) on number of roots per plot, Salable (>100 g) and unsalable roots $(<100 \mathrm{~g})$ (Levett, 1993), dry matter content of tubers, severity of damage by Cylas puncticollis and nematodes (Stathers et al., 2003). The sweet potato accessions were harvested plot by plot and the number of root tubers attacked by $C$. puncticollis and M. incognita counted and their percentages determined as:

$$
\frac{\text { Number of damaged sweet potato root tubers per plot }}{\text { Total number of sweet potato root tubers per plot }} \quad \times \quad \frac{100}{1}
$$

Then, the severity of damage was indicated for each accession using a five point (1-5), where:

$1=0 \%$ : no observable damage of sweet potato tubers by weevils (C. puncticollis) or M. incognita.

$2=1 \%-25 \%$ sweet potato root tubers attacked by $C$. puncticollis or $M$. incognita, indicating very little damage.

$3=26 \%-50 \%$ sweet potato root tubers attacked by $C$. puncticollis or $M$. incognita, indicating moderate damage.

$4=51 \%-75 \%$ sweet potato root tubers attacked by C. puncticollis or M. incognita, indicating considerable damage.

$5=76 \%-100 \%$ sweet potato root tubers attacked by C. puncticollis or M. incognita, indicating severe damage.

Similarly, skin colours and root flesh colours were determined using colour chart. The plant habits and ground cover of each sweet potato accession were determined using 1-5 point scale by visual method, where $1=1 \%-25 \%$ 
ground cover; $2=26 \%-49 \%(<50 \%)$ ground cover; $3=50 \%-75 \%$ ground cover; $4=76 \%-90 \%$ ground cover while $5=91 \%-100 \%$ ground cover $(>90 \%)$.

Dry matter content was determined within 24 hours of harvesting. Fresh root tubers of each accession were sliced into pieces and $100 \mathrm{~g}$ was dried in an oven at $80{ }^{\circ} \mathrm{C}$ for 24 hours until a constant mass was achieved and percentage dry weight determined as

$$
\frac{\text { Final weight }}{\text { Initial weight }} \times \frac{100}{1} \text {. }
$$

Duplication in accessions was determined by comparing the data obtained for the study, accessions with identical entries were regarded as duplications. The metric characters were subjected to analysis of variance and their means separated with the Least Significance Difference (LSD), using the procedure described by Wahua (1999). The yield and dry matter contents of the accessions for 2010 and 2011 were compared, using the t-test of paired observation (Wahua, 1999).

\section{Results and Discussion}

\subsection{Plant Habits and Ground Cover}

The sweet potato accessions had different growth habits (Table 1). Four accessions were extremely spreading (ES) types, namely $\mathrm{E}_{3}, \mathrm{~B}_{26}, \mathrm{E}_{27}$ and $\mathrm{E}_{10}$; six accessions were spreading types, namely $\mathrm{B}_{6}, \mathrm{~B}_{2}, \mathrm{E}_{11}, \mathrm{E}_{17}, \mathrm{E}_{14}$ and $\mathrm{E}_{7}$, while three were semi-erect, namely $\mathrm{E}_{5}, \mathrm{E}_{6}$ and $\mathrm{B}_{23}$. However, only two accessions $\left(\mathrm{B}_{21}\right.$ and TIS87/0087) were erect. The erect type had ground cover of less than $50 \%$, the semi-erect $50-75 \%$, the spreading type $76-90 \%$, while the extremely spreading type had ground cover of more than $90 \%$. Antiaobong and Bassey (2008) and Korieocha (2009) observed variability in several growth habits in sweet potato and reported that growth habit has a direct effect on the growth and yield of companion crops, soil characteristics, weeds control and may also aid in the selection of sweet potato in cropping systems. Similarly, IITA (1982) noted that spreading cowpea varieties have the abilities of spreading rapidly over the soil surface and intercepts all the available light, thus preventing and suppressing weeds, thus providing suitable soil environment for proper root development, especially when planted as a sole crop. Nangju et al. (1978) considered the spreading types more suitable for intercropping, since they have greater potential of utilizing available sunlight under cereal canopy than the erect and semi-erect types. However, the erect and semi-erect types may be preferred in crop mixtures if the companion crops are dwarf and shade tolerant.

\subsection{Skin and Root Flesh Colours of Sweet Potato}

Different skin and root flesh colours were observed among the sweet potato accessions (Table 1). Six accessions had white skin $\left(\mathrm{E}_{5}, \mathrm{E}_{3}, \mathrm{E}_{6}, \mathrm{E}_{14}, \mathrm{~B}_{23}\right.$ and $\left.\mathrm{E}_{10}\right)$, seven were pale pink $\left(\mathrm{B}_{6}, \mathrm{~B}_{26}, \mathrm{~B}_{2}, \mathrm{E}_{27}, \mathrm{E}_{17}, \mathrm{E}_{7}\right.$ and TIS 87/0087), while two were pink $\left(\mathrm{E}_{11}\right.$ and $\left.\mathrm{B}_{21}\right)$. Similarly, the root flesh colour of eleven accessions was creamy and this constituted the predominant flesh colour among the accessions. However, one accession was white, while three were yellow flesh types. Rees et al. (2001) reported that the colour characteristic of sweet potato roots constitutes an important factor in the choice of sweet potato by consumers, and could be used as genetic marker in predicting yield and culinary attributes of the roots. According to Rees et al. (2001), some farmers in Tanzania prefer white skin, yellow flesh tubers; others prefer white skin and orange flesh, while others prefer red skin and yellow flesh, red skin and white flesh and white skin and white flesh.

Kapinga et al. (1997) reported that the yellow or white root flesh were the most preferred by consumers. Rees et al. (2001) noted that consumers tend to prefer attractive root skin and flesh colours. Some traders preferred to sell yellow flesh roots, while others preferred white flesh roots. However, mixed skin and root colours were more preferred by consumers. Takahata et al. (1993) reported that carotenoid of orange flesh types were highly vitamin A active and almost exclusively $\beta$-carotene, yet most consumers prefer varieties with white or pale yellow flesh which contain very little carotene. According to Oyunga et al. (2001), increasing the consumption of the orange-flesh sweet potato roots and food could provide a significant proportion of the required dietary vitamin A intake. In general, vitamin A intake is often inadequate in children because of the seasonality of foods, early abandonment of exclusive feeding, high morbidity levels and the practice of not giving vitamin A-rich foods to young children (McGuire, 1993). Foods such as dairy and meat products containing pre-formed vitamin A are often too expensive for the majority of people in tropical and sub-tropical Africa. Plant foods which contain concentrated pro-vitamin A carotenoids can make a tremendous contribution to improved human health in these areas. The challenge however is to increase awareness, availability of carotene rich types, utilization and consumer acceptance (Oyunga et al., 2001). 
Table 1. Skin colour, flesh colour and severity of weevil attack and root cracks, plant habit and ground cover of sweet Potato accessions in Southeastern Nigeria

\begin{tabular}{|c|c|c|c|c|c|c|}
\hline Cultivars & $\begin{array}{l}\text { Skin } \\
\text { colour }\end{array}$ & $\begin{array}{l}\text { Root flesh } \\
\text { colour }\end{array}$ & $\begin{array}{l}\text { Pest (Cylas puncticollis } \\
\text { severity }\end{array}$ & $\begin{array}{l}\text { Severity of root } \\
\text { cracks }\end{array}$ & $\begin{array}{l}\text { Plant } \\
\text { habit }\end{array}$ & $\begin{array}{l}\text { Ground } \\
\text { cover }\end{array}$ \\
\hline E5 & White & Cream & 1 & 1 & SE & $50-57 \%$ \\
\hline B6 & Pale pink & White & 1 & 1 & $\mathrm{~S}$ & $76-90 \%$ \\
\hline E3 & White & Cream & 2 & 2 & ES & $>90 \%$ \\
\hline B26 & Pale pink & Cream & 5 & 2 & ES & $>90 \%$ \\
\hline B2 & Pale pink & Yellow & 1 & 5 & S & $76-90 \%$ \\
\hline E11 & Pink & Yellow & 2 & 2 & S & $76-90 \%$ \\
\hline E6 & White & Cream & 2 & 4 & SE & $50-75 \%$ \\
\hline E27 & Pale pink & Cream & 2 & 2 & ES & $>90 \%$ \\
\hline E17 & Pale pink & Yellow & 1 & 5 & S & $76-90 \%$ \\
\hline B21 & Pink & Cream & 1 & 1 & E & $2: \quad<50 \%$ \\
\hline E14 & White & Cream & 1 & 1 & $\mathrm{~S}$ & $4: \quad 76-90 \%$ \\
\hline E7 & Pale pink & Cream & 1 & 1 & $\mathrm{~S}$ & $76-90 \%$ \\
\hline B23 & White & Cream & 1 & 1 & $\mathrm{SE}$ & $50-75 \%$ \\
\hline E10 & White & Cream & 1 & 1 & ES & $>90 \%$ \\
\hline TIS87/0087 & Pale pink & Cream & 2 & 2 & $\mathrm{E}$ & $3: \quad<50 \%$ \\
\hline
\end{tabular}

Weevil and root crack severity rating scale 1-5, where:

$1=0 \%$ : no observable damage of sweet potato tubers by weevils (C. puncticollis) or M. incognita; $2=1 \%-25 \%$ sweet potato root tubers attacked by $C$. puncticollis or $M$. incognita, indicating very little damage; $3=26 \%-50 \%$ sweet potato root tubers attacked by $C$. puncticollis or $M$. incognita, indicating moderate damage; $4=51 \%-75 \%$ sweet potato root tubers attacked by $C$. puncticollis or M. incognita, indicating considerable damage and $5=$ $76 \%-100 \%$ sweet potato root tubers attacked by $C$. puncticollis or M. incognita, indicating severe damage. $\mathrm{S}=$ spreading; $\mathrm{ES}=$ Extremely spreading; $\mathrm{E}=$ Erect; $\mathrm{SE}=$ Semi-erect.

\subsection{Severity of Damage by Pests (Cylas puncticollis)}

The result as presented in Table 1 indicated that the accession $\mathrm{B}_{26}$ had the highest attack of C. puncticollis, followed by $\mathrm{E}_{3}, \mathrm{E}_{11}, \mathrm{E}_{6}$ and $\mathrm{E}_{27}$. Other accessions however, showed no apparent attack by the pest and may carry resistance genes. Ezulike et al. (2001) reported that resistance of the crop significantly influences the degree of damage by the pest and suggested the use of resistant types in Cylas prone areas. Similarly, the accessions $\mathrm{B}_{6}$, $\mathrm{E}_{17}, \mathrm{~B}_{21}, \mathrm{E}_{14}, \mathrm{E}_{7}, \mathrm{~B}_{23}$ and $\mathrm{E}_{10}$ were tolerant to the pest. The accession $\mathrm{B}_{26}$ which was highly susceptible to the pest could be eliminated from the recommended list for the area. Resistance of the accessions to pest based on root flesh colour or skin colour could not be established using the data generated for this study but Tewe et al. (2001) noted that the orange flesh clones were more susceptible to pests than the white flesh clones. Ngeve (2001) noted that since root yields and related characters were highly correlated with weevil damage, selection of accessions should be based on resistances to pest attack.

\subsection{Root Crack Infection by Moloidogyne Incognita}

The accessions $\mathrm{B}_{2}$ and $\mathrm{B}_{17}$ had the severest damage by nematodes disease caused by Meloidogyne incognita, hence they were regarded highly susceptible to the disease, followed by $\mathrm{E}_{6}$ with moderate damage. Very little damage was recorded for $\mathrm{E}_{11}$ and TIS 87/0087. The other accessions, namely: $\mathrm{E}_{5}, \mathrm{~B}_{6}, \mathrm{E}_{3}, \mathrm{~B}_{26}, \mathrm{E}_{27}, \mathrm{~B}_{21}, \mathrm{E}_{14}, \mathrm{E}_{7}$, $\mathrm{B}_{23}$ and $\mathrm{E}_{10}$ had no apparent damages by root cracks and are said to be highly resistant to the disease. Tewe et al. (2001) reported that losses from root knot nematodes range between 20-30\% in Nigeria and suggested the use of resistant accessions. Nwauzor et al. (2006) reported that the disease invades sweet potato roots in the region of tissue differentiation and infection in the primary roots cause galling of the roots. Secondary roots are deformed and tubers may crack due to nematode and suggested that resistant clones to root knot nematode be bred and released to farmers in this area. 


\subsection{Root Tuber Characteristics and Yield}

The result as presented in Table 2 shows the yield of sweet potato accessions in 2010 and 2011 and the highest root yield per plot and salable root was produced by $\mathrm{E}_{10}$, followed by $\mathrm{B}_{21}$, while the lowest number of salable roots was obtained from $\mathrm{E}_{17}$. Significant differences $(\mathrm{P}<0.05)$ were observed for number of root per plot, salable roots per hectare and unsalable roots per plot. However, no significant differences were observed for dry matter contents and unsalable root yield (tonnes/ha) of the sweet potato accessions. The accessions, $\mathrm{B}_{21}$ and $\mathrm{E}_{10}$ had the highest dry matter contents and salable roots and these are important factors for selection of sweet potato and serve as indicators of adaptability of the crop to local conditions (Antiaobong \& Bassey, 2008). Yield is an important factor which determines farmers' choice of sweet potato varieties (Njoku et al., 2009). Sweet potato has several industrial uses, for adhesives, textile, paper, flour (confectionery), alcohol production as well as energy source for batteries, all dependent on dry matter yield. Carey et al. (1997) considered dry matter content of sweet potato as determining the acceptability of accessions for large scale production and use for baking, flour production and in fortification of yam, cassava and other root crops. The high yielding types could be used in breeding programmes to upgrade the yield and dry matter contents of other accessions. The two accessions $\left(\mathrm{B}_{21}\right.$ and $\mathrm{E}_{10}$ ) were also found to be highly resistant to Cylas puncticollis and root knot nematode disease which affect sweet potato production in Southeastern Nigeria and could be incorporated into breeding programmes for the production of hybrid varieties in the cropping system of the area.

The result in Table 3 shows comparison of yield and dry matter content of sweet potato accessions for 2010 and 2011 cropping seasons. The t-test for yield and dry matter content indicated no significant year effect on yield and dry matter content of the accessions.

Table 2. Number of storage roots per plot, number of salable roots per plot, number of unsalable roots per plot, storage root yields ( $t / h a)$, salable root yield $(t / h a)$, unsalable root yield $(t / h a)$ and dry matter content of sweet potato accessions in Umudike, Southeastern Nigeria

\begin{tabular}{|c|c|c|c|c|c|c|c|c|c|c|c|c|c|c|c|}
\hline & \multirow[t]{2}{*}{ Accession } & \multirow{2}{*}{$\begin{array}{l}\text { Total } \\
\text { root } \\
\text { plot } \\
2010\end{array}$} & $\begin{array}{l}\text { storage } \\
\text { no per }\end{array}$ & \multicolumn{2}{|c|}{$\begin{array}{l}\text { Salable roots } \\
\text { number/plot }\end{array}$} & \multicolumn{2}{|c|}{$\begin{array}{l}\text { Unsalable } \\
\text { roots plot }\end{array}$} & \multirow{2}{*}{$\begin{array}{l}\text { Total } \\
\text { roots } \\
(\mathrm{t} / \mathrm{ha}) \\
2010\end{array}$} & \multirow{2}{*}{$\begin{array}{r}\text { storage } \\
\text { yield } \\
2011\end{array}$} & \multicolumn{2}{|c|}{$\begin{array}{l}\text { Salable root } \\
\text { yield (t/ha) }\end{array}$} & \multicolumn{2}{|c|}{$\begin{array}{l}\text { Unsalable } \\
\text { root yield } \\
(\mathrm{t} / \mathrm{ha})\end{array}$} & \multicolumn{2}{|c|}{$\begin{array}{l}\text { Dry matter } \\
\text { contents (\%) }\end{array}$} \\
\hline & & & 2011 & 2010 & 2011 & 2010 & 2011 & & & 2010 & 2011 & 2010 & 2011 & 2010 & 2011 \\
\hline 1 & E5 & $31.9^{\mathrm{de}}$ & $31.5^{\mathrm{cd}}$ & $16.8^{\mathrm{cd}}$ & $16.9^{\mathrm{d}}$ & $15.1^{\mathrm{e}}$ & 14.9 & $14.3^{\mathrm{g}}$ & $14.7^{\mathrm{e}}$ & $13.3^{\mathrm{e}}$ & $13.7^{\mathrm{f}}$ & 1.0 & 1.0 & 35.5 & 35.7 \\
\hline 2 & B6 & $40.5^{\mathrm{f}}$ & $40.9^{\mathrm{e}}$ & $26.6^{\mathrm{f}}$ & $26.8^{\mathrm{f}}$ & $13.9^{\mathrm{de}}$ & 14.1 & $16.0^{\mathrm{h}}$ & $16.8^{\mathrm{f}}$ & $15.2^{\mathrm{f}}$ & $16.0^{\mathrm{g}}$ & 0.8 & 0.8 & 32.6 & 32.6 \\
\hline 3 & E3 & $27.4^{\mathrm{d}}$ & $26.0^{c}$ & $14.6^{\mathrm{c}}$ & $13.4^{\mathrm{c}}$ & $12.8^{\mathrm{de}}$ & 12.6 & $6.0^{\mathrm{c}}$ & $6.2^{\mathrm{c}}$ & $5.6^{\mathrm{c}}$ & $5.9^{\mathrm{c}}$ & 0.4 & 0.4 & 32.4 & 32.6 \\
\hline 4 & B26 & $29.1^{\mathrm{d}}$ & $29.7^{\mathrm{c}}$ & $20.2^{\mathrm{e}}$ & $20.7^{\mathrm{e}}$ & $8.9^{\mathrm{c}}$ & 9.0 & $7.7^{\mathrm{de}}$ & $7.9^{\text {cd }}$ & $6.9^{\text {cd }}$ & $7.1^{\mathrm{d}}$ & 0.8 & 0.8 & 32.6 & 32.6 \\
\hline 5 & B2 & $34.0^{\mathrm{e}}$ & $34.0^{\mathrm{d}}$ & $21.8^{\mathrm{e}}$ & $21.6^{\mathrm{e}}$ & $12.2^{\mathrm{d}}$ & 12.4 & $10.3^{\mathrm{e}}$ & $10.9^{\mathrm{d}}$ & $9.8^{\mathrm{d}}$ & $10.4^{\mathrm{e}}$ & 0.5 & 0.5 & 32.4 & 32.4 \\
\hline 6 & E11 & $37.5^{\mathrm{ef}}$ & $37.1^{\mathrm{d}}$ & $25.9^{f}$ & $25.0^{\mathrm{f}}$ & $11.9^{\mathrm{d}}$ & 12.1 & $11.9^{\mathrm{f}}$ & $11.7^{\mathrm{de}}$ & $10.9^{\text {de }}$ & $10.7^{\mathrm{e}}$ & 1.0 & 1.0 & 36.1 & 36.3 \\
\hline 7 & E6 & $33.9^{\mathrm{e}}$ & $34.1^{\mathrm{d}}$ & $23.9^{\mathrm{ef}}$ & $24.1^{\mathrm{ef}}$ & $10.0^{\mathrm{d}}$ & 10.0 & $5.8^{\mathrm{c}}$ & $5.6^{\mathrm{c}}$ & $5.1^{\mathrm{c}}$ & $4.9^{\mathrm{c}}$ & 0.7 & 0.7 & 32.4 & 32.6 \\
\hline 8 & E27 & $35.8^{\mathrm{de}}$ & $36.2^{\mathrm{d}}$ & $20.8^{\mathrm{e}}$ & $21.2^{\mathrm{e}}$ & $15.0^{\mathrm{e}}$ & 15.0 & $6.7^{\mathrm{d}}$ & $6.7^{\mathrm{d}}$ & $6.3^{\mathrm{c}}$ & $6.3^{\mathrm{d}}$ & 0.4 & 0.4 & 29.3 & 29.3 \\
\hline 9 & E17 & $6.0^{\mathrm{a}}$ & $6.0^{\mathrm{a}}$ & $1.8^{\mathrm{a}}$ & $1.6^{\mathrm{a}}$ & $4.2^{\mathrm{a}}$ & 4.4 & $0.9^{\mathrm{a}}$ & $0.9^{\mathrm{a}}$ & $0.5^{\mathrm{a}}$ & $0.5^{\mathrm{a}}$ & 0.4 & 0.4 & 32.5 & 32.3 \\
\hline 10 & B21 & $58.8^{\mathrm{g}}$ & $59.2^{\mathrm{f}}$ & $43.2^{\mathrm{g}}$ & $43.4^{\mathrm{f}}$ & $15.6^{\mathrm{e}}$ & 15.8 & $10.9^{\text {ef }}$ & $10.7^{\mathrm{d}}$ & $10.3^{\mathrm{de}}$ & $10.1^{\mathrm{e}}$ & 0.6 & 0.6 & 40.0 & 40.4 \\
\hline 11 & E14 & $16.8^{\mathrm{c}}$ & $16.0^{\mathrm{b}}$ & $13.9^{\mathrm{c}}$ & $13.5^{\mathrm{c}}$ & $2.9^{\mathrm{a}}$ & 2.5 & $9.0^{\mathrm{e}}$ & $9.2^{\text {cd }}$ & $8.5^{\mathrm{d}}$ & $8.7^{\mathrm{de}}$ & 0.5 & 0.5 & 33.0 & 33.0 \\
\hline 12 & E7 & $12.5^{\mathrm{b}}$ & $12.9^{\mathrm{b}}$ & $5.7^{\mathrm{b}}$ & $5.7^{\mathrm{b}}$ & $6.8^{\mathrm{b}}$ & 7.2 & $3.0^{\mathrm{b}}$ & $3.0^{\mathrm{b}}$ & $2.4^{\mathrm{b}}$ & $2.4^{\mathrm{b}}$ & 0.6 & 0.6 & 36.0 & 36.0 \\
\hline 13 & B23 & $27.6^{d}$ & $27.8^{\mathrm{c}}$ & $17.1^{\mathrm{d}}$ & $17.5^{\mathrm{d}}$ & $10.5^{\mathrm{d}}$ & 10.3 & $8.4^{\text {de }}$ & $8.2^{\text {cd }}$ & $7.7^{\mathrm{cd}}$ & $7.5^{\mathrm{d}}$ & 0.7 & 0.7 & 32.7 & 32.7 \\
\hline 14 & E10 & $86.0^{\mathrm{i}}$ & $86.6^{\mathrm{g}}$ & $64.9^{\mathrm{i}}$ & $65.1^{\mathrm{h}}$ & $21.2^{\mathrm{f}}$ & 21.5 & $16.0^{\mathrm{h}}$ & $16.0^{\mathrm{f}}$ & $15.4^{\mathrm{f}}$ & $15.4^{\mathrm{g}}$ & 0.6 & 0.6 & 36.9 & 36.9 \\
\hline \multirow[t]{2}{*}{15} & TIS87/0087 & $61.2^{\mathrm{h}}$ & $61.6^{\mathrm{f}}$ & $45.5^{\mathrm{h}}$ & $45.9^{\mathrm{g}}$ & $15.7^{\mathrm{g}}$ & 15.7 & $10.2^{\mathrm{e}}$ & $10.6^{\mathrm{d}}$ & $9.5^{\mathrm{d}}$ & $9.9^{\mathrm{e}}$ & 0.7 & 0.7 & 35.2 & 35.6 \\
\hline & LSD $(0.05)$ & 3.14 & 3.15 & 2.18 & 2.19 & 1.22 & 1.22 & 1.02 & 1.02 & 1.07 & 1.07 & NS & NS & NS & NS \\
\hline
\end{tabular}


Table 3. t-test comparison of sweet potato yields and dry matter content for 2010 and 2011

\begin{tabular}{ll}
\hline Plant attribute & t-cal $(0.05)$ \\
\hline Total root tuber numbers/plot & $1.339^{\mathrm{NS}}$ \\
Number of salable root tubers/plot & $0.969^{\mathrm{NS}}$ \\
Number of unsalable root tubers/plot & $1.242^{\mathrm{NS}}$ \\
Total root tuber yield (ions/ha) & $0.973^{\mathrm{NS}}$ \\
Salable root tubers (tons/ha) & $0.919^{\mathrm{NS}}$ \\
Unsalable root tubers (tons/ha) & 0.0 \\
Dry matter content & $1.065^{\mathrm{NS}}$ \\
\hline
\end{tabular}

Critical $\mathrm{t}(0.05)=2.14$

\subsection{Duplicate Accessions in Collection}

The accession $\mathrm{E}_{27}$ was identified as the duplicate accession of TIS 87/0087 in the sweet potato germplasm collection. Gill (1989) ordered for development and use of efficient screening techniques to eliminate duplication of accession in order to develop only few restrictive collections for public use.

\section{Conclusion}

The sweet potato accessions differed significantly for yield, number of salable and unsalable roots. They also showed differences in skin colour and root flesh colour, resistances to pest, such as C. puncticollis and root knot nematode disease. Evaluation and characterization of sweet potato accessions could be used to identify and select accessions with high root yields and resistances for incorporation into breeding programmes. Plant habits of the accession could determine their combination in cropping systems in Nigeria. The study showed that $E_{27}$ was the duplicate accession of $87 / 0087$ and this accession could be eliminated from the list recommended for the area.

\section{References}

Antiaobong, E. E., \& Bassey, E. E. (2008). Constraints and prospects of sweet potato (Ipomoea batatas (L) Lam.) production in the humid environment of Southeastern Nigeria. Proceedings of the Second African Regional Conference on sustainable development, held at the Governor's Office Annex, Uyo, Nigeria, 2(3), 68-72.

Bouwkamp, J. C. (1985). Production requirements: Sweet potato production. In: J. C. Boukamp (Ed.). Natural Resource for the tropics (pp. 9-33). Boca Raton, Florida: CRC Press.

Carey, E. E., Cichuki, S. T., Ndolo, J. J., Turyamureeba, G., Kapinga, R., \& Lutaladio, N. B. (1976). Sweet potato breeding for Eastern, Central and Southern Africa (pp. 89-93). An overview. Proceedings of the Fourth Triennial Congress of the African Potato Association. Held in Pretoria, South Africa,

Chaltant, R. B., Janson, R. K., Seal, D. R., \& Schalk, J. M. (1996). Ecology and management of sweet potato $\begin{array}{lllll}\text { insects. Annual } & \text { Review }\end{array}$ http://dx.doi.org/10.1146/annurev.en.35.010190.001105

Chukwu, G. O. (2001). Seasonality and climatic period effects on crop evapotranspiration of sweet potato. In Akoroda, M. O., \& Ngeve, J. M. (Eds.), Root crops in the $21^{\text {st }}$ century (pp. 280-284). Proceedings of the $7^{\text {th }}$ Triennial Symposium of the International Society for Tropical Root Crops-African Branch. Held at the Centre International des Conference, Cotonou, Benin, 11-17 October, 1998.

Enwezor, W. O., UDO, E. J., Usoroh, N. J., Ayotade, K. A., Adepetu, J. A., Chude, V. O., \& Udegbe, C. I. (1989). Fertilizer use and management practices for crops in Nigeria (pp. 69-70). Fertilizer Procurement and Distribution Division, Ministry of Agriculture, Water Resources and Rural Development, Lagos.

Ezulike, T. O., Anioke, S. C., \& Odurukwe, S. O. (2001). Integrated control of sweet potato weevil, Cylas puncticollis (Boh) in Southeastern Nigeria. In: Akoroda, M. O., \& Ngeve, J. M. (eds.), Root Crops in the $21^{s t}$ Century (pp. 645-648). Proceedings of the $7^{\text {th }}$ Triennial Symposium of the International Society of Tropical Root crops-African Branch, 11-17 October, 1998.

FAO. (2004). FAOSTAT-Data base result 228; Records of sweet potato production 2002-2004. 
Gill, K. S. (1989). Germplasm collections and the public plant breeder, In: Brown A. H. D., Marshall D. R., Frankel O. H., \& J. T. William (Eds), The use of plant genetic resources (pp. 3-16). Cambridge: Cambridge University Press.

Gill, L. S. (1988). Taxonomy of flowering plants (p. 22). Onitsha, Nigeria: African-FEB Publishers.

IITA. (1982). Cowpea Training Manual (pp. 42-43). International Institute of Tropical Agriculture Manual Series No. 11,

Kapinga, R. E., Ewell, P. T., \& Jeremiah, S. C. (1997). Sweet potato in Tanzanian farming and food systems. Implications for Research (p. 47), Ministry of Agriculture and Livestock Development, Tanzania and International Potato Centre (CIP), Nairobi Kenya.

Korieocha, D. S., Ogbonna, M. C., Nwokocha, C. C., Echendu, T. N. C., \& Okorocha, E. O. A. (2009). Effect of time of herbicide application and sweet potato morpho-types on the effectiveness of herbicide on weeds (pp. 12-16). Proceedings of the $43^{\text {rd }}$ Annual Conference of Agricultural Society of Nigeria. Held at National Universities Commission, Abuja, Tuesday $20^{\text {th }}$-Friday $23^{\text {rd }}$ October.

Kumar, T. P., \& Peter, K. V. (2000). Breeding of vegetable crops. In Chopra, V. L. (Ed), Plant Breeding: Theory and Practice (p. 262). New Delhi: Oxford and IBH Publishing Co. Pvt Ltd.

Levett, M. P. (1993). The effects of methods of planting cuttings of sweet potato (Ipomoea batatas (L) Lam) on yield. Tropical Agriculture (Trinidad), 70(2), 110-115.

McGuire, J. (1993). Addressing micronutrient malnutrition. In: United Nations Subcommittee on Nutrition (SCN) News. No. 9, ACC/SCN, Geneva, Switzerland.

Nangju, D. J., Wein, H. C., \& Ballaux, J. C. (1978). Cowpea-maize intercropping studies. Effect of plant type and planting pattern and date IITA (pp. 22-28), Ibadan, Nigeria,.

Ngeve, J. M. (2001). Field performance and reaction to weevils of improved and local sweet potato genotypes in Cameroon. In M. O.Akoroda, \& J. M. Ngeve (Eds.), Root Crops in the 21 $1^{\text {st }}$ Century (pp. 290-297). Proceedings of the $7^{\text {th }}$ Triennial Symposium of the International Society for Tropical Root Crops-African Branch, 11-17 October,.

Njoku, J. C., Muoneke, C. O., Okocha, P. I., \& Ekeleme, F. (2009). Effect of propagule size and intra-row spacing on the growth and yield of sweet potato in a humid agro-ecological zone. Nigerian Agricultural Journal, 40(1), 115-124.

Nwauzor, E. C., Afuape, S. O., Korieocha, D. S., \& Ezulike, T. O. (2006). Studies on the use of Neem leaf preparation for the control of Cylas puncticollis damage of tubers in sweet potato production. Proceedings of the $40^{\text {th }}$ Annual Conference of the Agricultural Society of Nigeria (pp. 676-708). Held at the National Root Crops Research Institute, Umudike-Nigeria.

Onwueme, I. C. (1978). The tropical tuber crops (pp. 187), John Wiley and Sons, New York.

Njoku, J. C., Muoneke, C. O., Okocha, P. I., \& Ekeleme, F. (2009). Effect of propagule size and intra-row spacing on the growth and yield of sweet potato in humid agro-ecological zone. The Nigerian Agricultural Journal, 40(1 \& 2), 115-124.

Oyunga, M. A., Hagenimama, V., Kurtz, K., \& Low, J. (2001). Increasing vitamin A intake through promotion of orange-fleshed sweet potatoes in Western Kenya: A women centered approach. In M. O. Akoroda, \& J. M. Ngeve (Eds.), Root Crops in the $21^{\text {st }}$ Century (pp. 748-755). Proceedings of the $7^{\text {th }}$ Triennial Symposium the International Society for Tropical Root Crops-African branch 11-17 October, 1998,

Rees, D., Kapinga, R., Jeremiah, S., \& Rwiza, E. (2001). Preferences and selection criteria of sweet potato varieties in rural and urban areas Tanzania. In M. O. Akoroda, \& J. M. Ngeve (Eds.), Root Crops in the $21^{\text {st }}$ Century (pp. 417-423). Proceedings of the $7^{\text {th }}$ Triennial Symposium of the International Society for Tropical Root Crops-African Branch, held at the Centre International des Conferences, Cotonou, Republic of Benin, 11-17 October, 1998.

Stathers, T. E., Ress, F., Kabi, S., Mbilinyi, L., Smit, N., Koizya, H., ... Jeiffrics, D. (2003). Sweet potato infestation by Cylas species in East Africa. I. Cultivar differences in field manifestation and the role of plant factors. International Journal of Pest Management, 49, 131-140. http://dx.doi.org/10.1080/0967087021000043085

Takahata, Y., Noda, T., \& Nagata, T. (1993). HPLC determination of $\beta$-carotene of sweet potato cultivars and its relationship with colour values, Japan Journal of Breeding, 43, 421-427. 
Tewe, O. O., Abu, O. A., Ojeniyi, E. F., \& Nwokocha, N. H. (2001). Status of sweet potato production, utilization and marketing in Nigeria. In M. O. Akoroda, \& J. M. Ngeve (Eds.), Root Crops in the $21^{\text {st }}$ Century (pp. 65-74). Proceedings of the $7^{\text {th }}$ Triennial Symposium of the International Society for Tropical Root Crops, African Branch, 11-17 October, 1998.

Wahua, T. A. T. (1999). Applied statistics for scientific studies. Afrika-Link Books (pp. 16-38). Owerri-Nigeria.

Woolfe, J. A. (1993). Sweet potato: An untapped food resource. In Collaboration with International Potato Centre (CIP), Peru (pp. 16-19). Cambridge: Cambridge University Press. 